\title{
DETERMINAN KEPUASAN NASABAH DALAM MEMBENTUK LOYALITAS NASABAH PT BTN CABANG AMBON
}

\author{
CYNTHIA IMELDA TJOKRO* \\ Jurusan Administrasi Bisnis, Politeknik Negeri Ambon, Wailela, Ambon
}

\begin{abstract}
ABSTRAK: Penelitian ini ingin mengetahui faktor-fator yang merupakan determinan kepuasan dalam rangka membentuk loyalitas nasabah PT BTN Cabang Ambon. Tujuan dari penelitian ini untuk menganalisis pengaruh faktor kualitas layanan, kepercayaan, nilai pelanggan, keunggulan produk, citra perusahaan terhadap kepuasan dan loyalitas nasabah PT BTN Cabang Ambon. Penelitian ini dilakukan di PT. BTN Cabang Ambon. Analisis data menggunakan analisa jalur untuk mengetahui pengaruh variabel independen terhadap variabel dependen, baik secara langsung maupun tidak langsung. Hasil penelitian ini menunjukkan kualitas layanan (X1), kepercayaan (X2), nilai pelanggan (X3), Keunggulan Produk (X4), dan Citra Perusahaan (X5) memengaruhi kepuasan (Y1) dan loyalitas nasabah (Y2), baik secara langsung maupun tidak langsung.
\end{abstract}

Kata kunci: kualitas layanan, kepuasan pelanggan, and loyalitas

ABSTRACT: This study aims to investigate the determinant factors of satisfaction in order to form customer loyalty PT BTN Ambon Branch. The purposes of this research are to analyze the influence of service quality, trust, customer value, product superiority, corporate image to satisfaction and customer loyalty of PT BTN Ambon Branch. This research is conducted at PT. BTN Ambon Branch. Data analysis using path analysis is used to discover the influence of independent variable to dependent variable, either directly or indirectly. The results of this study indicate that service quality (X1), trust (X2), customer value (X3), Product Superiority (X4), and Corporate Image (X5) affect satisfaction (Y1) and customer loyalty (Y2), either directly or indirectly.

Keywords: service quality, customer satisfaction, and loyalty

* Surel Korespondensi Penulis: cynthiaimeldatjokro@gmail.com 


\section{PENDAHULUAN}

Perusahaan yang ingin berkembang dan mendapatkan keunggulan kompetitif harus mampu memberikan produk berupa barang atau jasa yang berkualitas dengan harga terjangkau, penyerahan cepat, dan memberikan pelayanan yang baik kepada konsumennya dibanding dengan kompetitornya. Untuk memenuhi kepuasan nasabah pada industri perbankan, kualitas pelayanan sangat penting bagi perusahaan untuk dikelola dengan baik agar memenuhi keinginan konsumen (Lovelock, 1988). Oleh karena itu perlu diteliti faktor-faktor yang memengaruhi kepuasan nasabah.

Masyarakat sebagai pengguna jasa kini semakin selektif dalam memilih bank untuk menitipkan dana yang dimiliki untuk menghindari risiko kehilangan dana akibat buruknya kinerja suatu bank. Dalam hal ini unsur kepercayaan menjadi faktor kunci bagi bank untuk memenangkan persaingan (Doney dan Cannon, 1997). Bisnis perbankan merupakan bisnis jasa yang berdasar pada kepercayaan yang didukung keunggulan produk (Mital et al., (1998), nilai nasabah (Tax, Brown dan Chandrashekaran, 1998; Too, Souchon dan Thirkell, 2000), kualitas pelayanan yang diberikan (Parasuraman, Ziethaml dan Berry, 1988) dan citra perusahaan (Aaker dan Keller, 1990; Efendi, 2017 \& 2018) sehingga masalah rasa percaya, keunggulan produk, nilai nasabah, kualitas layanan dan citra perusahaan menjadi faktor yang sangat menentukan keberhasilan bisnis ini.

Dari hasil beberapa penelitian terdahulu (Mital et al., 1998; Doney dan Cannon, 1997; Slater dan Narver, 1994; Butz dan Goodstein,1996; Parasuraman et al., 1994; Aaker dan Keller, 1990; dan Fornell, 1992), penelitian ini melakukan pengembangan dengan menggunakan lima faktor yang memengaruhi kepuasan nasabah yang didukung oleh penelitian terdahulu, kelima faktor tersebut adalah keunggulan produk, rasa percaya, nilai nasabah, kualitas layanan dan citra perusahaan. Etika organisasi juga dianggap sebagai salah satu bagian yang menjadi pertimbangan bagi para calon nasabah dalam mempertimbangkan pilihan dalam menabung (Parmitasari et al. 2018; Syariati, 2012), karenanya dibutuhkan kecerdasan emosional para pemasar dalam mempertimbangkan hal ini (Said \& Amiruddin, 2016); yang mana akan kaitmengait dengan isu kesejahteraan mereka (Nurfarhana \& Said, 2017). Karenanya organisasi dengan budaya yang kuat akan mendorong terciptanya kinerja pemasar yang maksimal (Awaluddin,2016; Suhartini \& Anisa, 2017).

Berdasarkan latar belakang di atas maka penelitian ini dilakukan dengan judul “Determinan Kepuasan Nasabah Dalam Membentuk Loyalitas Nasabah PT BTN Cabang Ambon".

Penelitian ini bertujuan untuk menguji dan menganalisis pengaruh kepercayaan, nilai pelanggan, keunggulan produk, dan citra perusahaan terhadap kepuasan dan loyalitas nasabah PT BTN Cabang Ambon.

Dari uraian di atas, masalah yang akan dibahas dalam penelitian ini adalah sebagai berikut :

1. Apakah terdapat pengaruh signifikan kualitas layanan terhadap kepuasan nasabah PT BTN Cabang Ambon. 
2. Apakah terdapat pengaruh signifikan kepercayaan terhadap kepuasan nasabah PT BTN Cabang Ambon.

3. Apakah terdapat pengaruh signifikan nilai pelanggan terhadap kepuasan nasabah PT BTN Cabang Ambon.

4. Apakah terdapat pengaruh signifikan keunggulan produk terhadap kepuasan nasabah PT BTN Cabang Ambon.

5. Apakah terdapat pengaruh signifikan citra perusahaan terhadap kepuasan nasabah PT BTN Cabang Ambon.

6. Apakah terdapat pengaruh signifikan kualitas layanan terhadap loyalitas nasabah PT BTN Cabang Ambon.

7. Apakah terdapat pengaruh signifikan kepercayaan terhadap loyalitas nasabah PT BTN Cabang Ambon.

8. Apakah terdapat pengaruh signifikan nilai pelanggan terhadap loyalitas nasabah PT BTN Cabang Ambon.

9. Apakah terdapat pengaruh signifikan keunggulan produk terhadap loyalitas nasabah PT BTN Cabang Ambon.

10. Apakah terdapat pengaruh signifikan citra perusahaan terhadap loyalitas nasabah PT BTN Cabang Ambon.

11. Apakah terdapat pengaruh signifikan kepuasan terhadap loyalitas nasabah PT BTN Cabang Ambon.

\section{TINJAUAN TEORITIS}

Kualitas Layanan (Quality of Service)

Perusahaan yang ingin memenangkan persaingan akan memberikan perhatian penuh pada kualitas. Hal ini akan berdampak positif terhadap bisnis melalui dua cara, yaitu terhadap biaya produksi dan terhadap pendapatan (Gasperz, 1997). Dampak terhadap biaya produksi terjadi melalui proses pembuatan produk yang memiliki conformance yang tinggi terhadap standar sehingga bebas dari kerusakan. Dampak terhadap pendapatan terjadi melalui peningkatan penjualan atas produk berkualitas Kualitas memiliki banyak definisi yang berbeda, dan bervariasi dari yang konvensional sampai yang lebih strategik (Gaspersz, 1997). Definisi konvensional menggambarkan karakteristik langsung dari produk seperti perfomance, keandalan (reliability), dan mudah dalam penggunaan (easy of use), estetika (esthetic). Sedangkan definisi strategic dari kualitas adalah segala sesuatu yang mampu memenuhi keinginan atau kebutuhan nasabah (meeting the needs of customers).

Menurut Kotler (1997) kualitas harus dimulai dari kebutuhan nasabah dan berakhir pada persepsi nasabah. Berarti bahwa citra kualitas yang baik bukan dilihat dari persepsi pihak penyedia jasa, melainkan berdasar persepsi para pelanggan. Persepsi nasabah terhadap kualitas merupakan perilaku menyeluruh atas keunggulan suatu jasa. Hal ini didukung oleh pendapat Band (1989) bahwa yang dimaksud kualitas adalah perceived quality, yaitu perspektif nasabah.

Konsistensi kualitas jasa sangat sulit untuk dijaga. Dengan demikian, kualitas jasa memiliki ketergantungan yang tinggi pada kinerja pekerja, sumber 
organisasional, dimana mereka tidak dapat dikontrol semudah komponen barang diproduksi (Zeithaml, 1987).

Parasuraman et. al (1990) telah mengembangkan suatu alat ukur kualitas layanan yang disebut SERVQUAL (Service Quality) untuk mengukur persepsi nasabah atas kualitas layanan. Menurut mereka kualitas layanan meliputi lima dimensi yaitu tangibles, mencakup fasilitas fisik, perlengkapan, personilnya dan sarana komunikasi. Reliability, yaitu kemampuan untuk menghasilkan kinerja pelayanan yang dijanjikan secara akurat dan pasti. Artinya pelayanan harus tepat waktu dan dalam spesifikasi yang sama, tanpa kesalahan, kapanpun pelayanan tersebut diberikan. Responsiveness, yaitu kemampuan para karyawan untuk membantu para nasabah dan memberikan layanan dengan tanggap. Assurance, yaitu kemampuan, kesopanan, dan sifat dapat dipercaya yang dimiliki oleh para staff, bebas dari bahaya, risiko dan keragu-raguan. Serta empathy, yaitu kemudahan dalam melakukan hubungan, komunikasi yang baik, perhatian pribadi dan memahami kebutuhan nasabah.

Variabel kualitas layanan dalam penelitian ini mengadopsi konsep yang dikemukakan oleh Parasuraman, et al. (1988) yang meliputi tangibles, reliability, responsiveness, assurance, dan empathy.

\section{Kepercayaan (Trust)}

Oliver (1997) menyatakan rasa percaya (trust) sering dipandang memiliki karakteristik hubungan jangka panjang. Anderson dan Weitz (1989) mendefinisikan rasa percaya sebagai kondisi psikologis yang terdiri dari niat/intensi untuk menerima kelemahan berdasarkan pengharapan positif terhadap niat atau perilaku orang lain, dari definisi ini perlu dicatat 2 bagian penting yaitu: (1) Rasa percaya berhubungan dengan pengharapan positif terhadap niat atau perilaku dari partner, sehingga fokusnya adalah pada keyakinan partnernya akan bertindak dengan tanggung jawab, menunjukkan integritas dan tidak akan melukai partnernya. (2) Rasa percaya berhubungan dengan niat seseorang mengandalkan partnernya akan menerima kelemahankelemahan yang kontekstual.

Variabel kepercayaan pelanggan yang digunakan dalam penelitian ini mengadopsi konsep yang dikemukakan oleh Tax, Brown dan Chandrashekaran (1998) serta Doney dan Cannon, (1997) meliputi kepercayaan atas kebenaran informasi yang diterima, kepercayaan atas penanganan keluhan nasabah, kepercayaan atas pemenuhan janji perusahaan, dan kepercayaan atas risiko produk yang ditawarkan.

\section{Nilai Pelanggan (Customer Value)}

Konsep nilai nasabah memberikan gambaran tentang nasabah suatu perusahaan, mempertimbangkan apa yang mereka inginkan, dan percaya bahwa mereka memperoleh manfaat dari suatu produk (Woodruff, 1997). Band (1991) melihat perlunya lintas fungsional dalam suatu perusahaan, yaitu pemasaran, operasi dan sumber daya manusia sebagai prasyarat dalam mengelola nilai nasabah. Elemen mengelola hubungan dengan pelanggan dan mengelola persepsi nilai adalah tugas dari fungsi pemasaran, elemen meningkatkan kemampuan para karyawan sebagai value creator adalah tugas 
dari manajemen sumber daya manusia, sedangkan elemen meningkatkan kinerja kualitas adalah tugas dari fungsi operasi (Sinkula et al, 1997).

Nilai pelanggan merupakan keseluruhan penilaian pelanggan tentang kegunaan suatu produk yang berdasar pada persepsi tentang apa yang diterima dan apa yang diberikan (Zeithaml, 1987). Persepsi pembeli tentang nilai yang menggambarkan sebuah perbandingan antara kualitas atau keuntungan yang mereka rasakan dalam produk dengan pengorbanan yang mereka rasakan ketika membayar harga produk.

Konsep nilai nasabah mengindikasikan suatu hubungan yang kuat terhadap kepuasan konsumen atau nasabah (Woodruff, 1997). Dimana konsep tersebut menggambarkan pertimbangan yang evaluatif pelanggan tentang produk yang mereka konsumsi. Nilai yang diinginkan nasabah terbentuk ketika mereka membentuk persepsi bagaimana baik buruknya suatu produk dimainkan dalam situasi penggunaan. Mereka mengevaluasi pengalaman penggunaan pada atribut yang sama, seperti telah dijelaskan diatas bahwa atribut yang dimaksud disini adalah merk dan kualitas pelayanan atas produk. Nilai yang diterima bisa mengarahkan secara langsung pada formasi perasaanperasaan kepuasan secara keseluruhan. Kepuasan secara menyeluruh merupakan perasaan-perasaan nasabah dalam respon untuk evaluasi dari satu atau lebih pengalaman konsumen dalam penggunaan suatu produk. Dengan tercapainya tingkat kepuasan konsumen yang optimal maka mendorong terciptanya loyalitas di benak nasabah yang merasa puas tadi.

Variabel nilai pelanggan dalam penelitian ini mengadopsi konsep yang dikemukakan oleh Tax, Brown dan Chandrashekaran (1998) yang meliputi penilaian terhadap keunggulan, rasa ketertarikan secara keseluruhan, dan penilaian terhadap manfaat keseluruhan perusahaan.

\section{Keunggulan Produk (Product Exellence)}

Penelitian terdahulu (Li dan Calantone, 1998 serta Cooper, 1992) menyarankan atribut produk seperti kualitas produk, reliabilitas, kebaruan dan keunikan, memberikan gambaran yang lebih nyata dari kemampuan perusahaan untuk memenuhi kebutuhan pelanggan dan "perbedaanperbedaan antara berbagai alternatif pada atribut-atribut yang penting memberikan keunggulan yang jelas" (Li dan Calantone, 1998). Sementara Mital et al (1998) mengemukakan kinerja yang negatif pada produk atribut mempunyai efek negatif pada kepuasan keseluruhan dan kerja yang positif mempunyai pengaruh positif pada atribut yang sama dan kepuasan keseluruhan menunjukkan pengurangan sensitivitas pada tingkat kinerja atribut.

Pada dasarnya kesempatan atau peluang suatu perusahaan dalam memutuskan untuk menciptakan produk baru didasarkan pada adanya kesenjangan antara kepuasan pelanggan dengan harapan pelanggan terhadap suatu produk. Kodama (1995) dalam Song dan Parry (1997) mengemukakan bahwa yang terpenting dalam pengembangan produk baru adalah kemampuan untuk mengubah jarak permintaan (demand) dengan harapan yang samarsamar atau tidak jelas menjadi produk yang nyata (well-defined) 
Untuk mengisi kesenjangan tersebut dengan melakukan inovasi terhadap produk yang sudah ada maupun mengembangkan produk yang benar-benar baru. Selain itu, perusahaan juga harus mempertimbangkan agar produk baru yang dikembangkan dapat diterima dalam persaingan. Adapun karakteristik keunggulan produk baru dalam persaingan dapat ditemukenali dari beberapa hal antara lain yaitu kualitas produk yang bersangkutan; bentuk dan kemasan yang unik; pelayanan purna jual yang memuaskan; fungsi kepeloporan produk; aneka atau multifungsi produk.

Perusahaan yang ingin mempunyai produk kompetitif harus berorientasi pada teknologi (Gatignon dan Xuereb, 1997). Menurut Urban dan Hauser (1998), penolakan atau kegagalan suatu produk adalah karena produk tersebut tidak dapat mengikuti perkembangan teknologi sehingga strategi yang perlu dikembangkan perusahaan adalah strategi yang bersifat proaktif. Strategi proaktif dalam pengembangan produk baru dan kebijakan terhadap pasar atau pelanggan. Atribut yang mendukung keunggulan produk adalah dengan melakukan diferensiasi produk yang komponen-komponennya antara lain produk tersebut harus lebih inovatif dibandingkan dengan produk yang sudah ada, produk tersebut harus mempunyai kualitas yang tinggi, dan yang ketiga produk harus dapat menjembatani keinginan dari konsumen dengan baik, dalam hal ini diterjemahkan sebagai fungsi daripada produk tersebut.

Variabel keunggulan produk dalam penelitian ini mengadopsi konsep yang dikemukakan oleh Song dan Parry (1997), yang meliputi kualitas, keunikan, dan multifungsi.

\section{Citra Perusahaan (Company Impression)}

Citra perusahaan didefinisikan sebagai sebuah persepsi mengenai kualitas yang digabungkan dengan nama (Aaker dan Keller, 1990). Fungsi utama dari citra perusahaan adalah menjadi fasilitas pilihan ketika pedoman instrinsik atau atributatribut tampak sulit atau tidak mungkin untuk dilakukan. Pedoman instrinsic meliputi komposisi fisik atau teknikal dari produk. Nama merk telah didefinisikan sebagai sebuah pedoman ekstrinsik, sehinggamenjadi sebuah atribut yang digabungkan dengan jasa tetapi tidak menjadi bagian fisik jasa itu sendiri.

Variabel citra perusahaan dalam penelitian ini mengadopsi konsep yang dikemukakan oleh Aaker dan Keller (1990) yang meliputi citra perusahaan dibandingkan pesaingnya, citra produk, dan citra pelayanan.

\section{Kepuasan (Satisfaction)}

Saat ini kepuasan nasabah menjadi fokus perhatian oleh hampir semua pihak, baik pemerintah, pelaku bisnis, konsumen dan sebagainya. Hal ini disebabkan semakin baiknya pemahaman mereka atas konsep kepuasan nasabah sebagai strategi untuk memenangkan persaingan di dunia bisnis. Kepuasan nasabah merupakan hal yang penting bagi penyelenggara jasa, karena nasabah akan menyebarluaskan rasa puasnya kepada calon nasabah, sehingga akan menaikkan reputasi pemberi jasa.

Tse dan Wilton (1988) menyatakan kepuasan nasabah adalah respon nasabah terhadap evaluasi ketidaksesuaian yang dirasakan setelah 
pemakaiannya. Engel, et al. (1995) mendefinisikan kepuasan nasabah sebagai evaluasi purna beli di mana alternatif yang dipilih sekurang-kurangnya sama atau melampaui harapan nasabah, sedangkan ketidakpuasan timbul apabila hasil tidak memenuhi harapan nasabah. Sedangkan Kotler (1997) menyatakan kepuasan nasabah adalah tingkat keadaan perasaan seseorang yang merupakan hasil perbandingan antara penilaian kinerja/hasil akhir produk dalam hubungannya dengan harapan nasabah. Karena itu, kepuasan atau ketidakpuasan nasabah merupakan perbedaan/kesenjangan antara harapan sebelum pembelian dengan kinerja atau hasil yang dirasakan setelah pembelian.

Variabel kepuasan dalam penelitian ini mengadopsi konsep yang dikemukakan oleh Engel, et al. (1995) dan Kotler (1997) yang meliputi kepuasan keseluruhan, kepuasan atas produk, dan perbandingan antara harapan dan kenyataan.

\section{Loyalitas (Loyalty)}

Setelah nilai suatu produk sampai di tangan pelanggan dan kemudian pelanggan dapat menggunakan atau mengkonsumsinya secara optimal, sehingga konsumen merasa puas (Mital et al. 1998). Kepuasan yang dirasakan oleh pelanggan mempunyai konsekuensi perilaku berupa komplain dan loyalitas pelanggan, sehingga apabila organisasi atau perusahaan dapat memperhatikan segala hal yang dapat membentuk kepuasan pelanggan, maka kepuasan yang dirasakan oleh pelanggan secara keseluruhan akan terbentuk. Dimana kepuasan keseluruhan didefinisikan sebagai pernyataan afektif tentang reaksi emosional terhadap pengalaman atas produk atau jasa, yang dipengaruhi oleh kepuasan pelangan terhadap produk tersebut dan dengan informasi yang digunakan untuk memilih produk. Kepuasan konsumen atau pelanggan merupakan suatu darah kehidupan setiap perusahaan, sehingga kepuasan pelanggan merupakan salah satu elemen penting dalam peningkatan kinerja pemasaran dalam suatu perusahaan atau organisasi.

Kepuasan yang dirasakan pelanggan dapat meningkatkan intensitas membelinya. Dengan kepuasan pelanggan yang optimal, mendorong terciptanya loyalitas di benak pelanggan. Loyalitas pelanggan dipandang sebagai kekuatan hubungan antara sikap relatif seseorang dan bisnis berulang. Hubungan ini dijembatani oleh norma-norma sosial dan faktor-faktor situasional. Anteseden kognitif, afektif, dan konatif dari sikap relatif diidentifikasikan karena memiliki andil pada loyalitas, demikian juga konsekuensi perilaku, perceptual dan motivasional.

Variabel loyalitas nasabah dalam penelitian ini mengadopsi konsep yang dikemukakan oleh Selnes (1993) yang meliputi sikap untuk tetap memilih produk perusahaan walau terjadi kenaikan harga, rekomendasi kepada orang lain, dan sikap untuk tetap memilih produk perusahaan walau ada tawaran dari pesaing.

Pengaruh Kualitas Layanan, Kepercayaan, Nilai Pelanggan, Keunggulan Produk dan Citra Perusahaan Terhadap Kepuasan dan Loyalitas Nasabah 
Hubungan antara kualitas layanan dengan kepuasan nasabah penting bagi perusahaan, dan peneliti, karena perusahaan (penyedia jasa) perlu mengetahui apakah tujuan perusahaan harus memiliki nasabah yang puas dengan kinerja perusahaan atau memberikan "kualitas layanan yang dipersepsikan" pada tingkat maksimum. Dengan demikian kepuasan dapat memengaruhi evaluasi nasabah terhadap kualitas layanan. Pentingnya isu tersebut telah mendorong usaha untuk memperjelas hubungan antara kepuasan dan kualitas layanan (Parasuraman, et al., 1985; 1988; 1990 dan 1994). Hasil penelitian mereka menyimpulkan bahwa semakin tinggi tingkat kualitas layanan yang dipersepsikan, semakin besar kepuasan nasabah. Hal ini disebabkan kualitas yang dipersepsikan merupakan kemampuan memutuskan tentang kesempurnaan atau superioritas entitas, atau juga merupakan suatu bentuk sikap, evaluasi secara menyeluruh dalam jangka panjang.

Rasa percaya terhadap perusahaan diukur oleh sikap nasabah atas pengalaman dalam berhubungan dengan perusahan, informasi yang disediakan oleh perusahaan dan perhatian perusahaan kepada nasabah (Doney dan Cannon, 1997). Mereka juga menyatakan dengan membangun rasa percaya yang relatif lebih sulit dan memakan waktu yang lebih kompleks, akan memberikan sumbangan yang berarti dalam hubungan pembeli-penjual dan akan meningkatkan kesetiaan yang pada akhirnya akan meningkatkan kepuasan nasabah. Perusahaan hanya dapat eksis dan bertahan bila mempunyai keunggulan-keunggulan unik dibandingkan dengan pesaingnya. Bila perusahaan tidak mempunyai keunggulan unik, maka pesaingnya dapat menggeser posisi strategiknya. Metode yang berfokus pada nasabah adalah identifikasi pemilihan dari kompetensi khusus, yang didasarkan pada tingkat dan pola unik baik pada keterampilan maupun sumber daya, dan disebarkan melalui cara yang tidak dapat ditiru oleh pesaing. Mital et al (1998) menunjukkan bahwa diferensiasi yang menjadi keunggulan produk berpotensi untuk meningkatkan kepuasan nasabah.

Nilai nasabah merupakan kualitas yang dirasakan nasabah yang disesuaikan dengan harga relatif dari produk yang dihasilkan oleh suatu perusahaan (Slater dan Narver,1994). Konsep nilai nasabah mengindikasikan suatu hubungan yang kuat terhadap kepuasan nasabah, dimana konsep tersebut menggambarkan pertimbangan yang evaluatif nasabah tentang produk yang ditawarkan.

Dalam pemasaran, kesadaran dan image sebuah merek dan reputasi jasa memengaruhi keputusan konsumen untuk membeli. Pada konteks ini, reputasi atau merek menjadi sebuah masalah dari sikap dan kepercayaan terhadap kesadaran pada merek dan image, keputusan konsumen dan kesetiaan konsumen (Fornel, 1992). Citra perusahaan yang melekat pada benak konsumen akan menambah kepuasan konsumen dan mengakibatkan loyalitas konsumen terhadap perusahaan dan produknya.

\section{Hubungan Kepuasan Nasabah Terhadap Loyalitas Nasabah}

Hubungan antara kepuasan nasabah dan loyalitas nasabah telah banyak diteliti dalam beberapa studi. Fornell (1992) mengatakan bahwa kepuasan nasabah memengaruhi perilaku membeli, dimana nasabah yang puas cenderung 
menjadi nasabah yang loyal, namun nasabah yang loyal tidak perlu puas. Loyalitas berarti kemampuan perusahaan memposisikan produknya dibenak nasabah, dimana perusahaan berusaha menganggap nasabah sebagai mitranya dengan cara memantapkan keyakinan nasabah, selalu berinteraksi, bila perlu mengembangkan demi kemajuan bersama (Kertajaya, 1999).

Dari uraian di atas, dapat dikembangkan suatu kerangka konseptual pada Gambar 1.

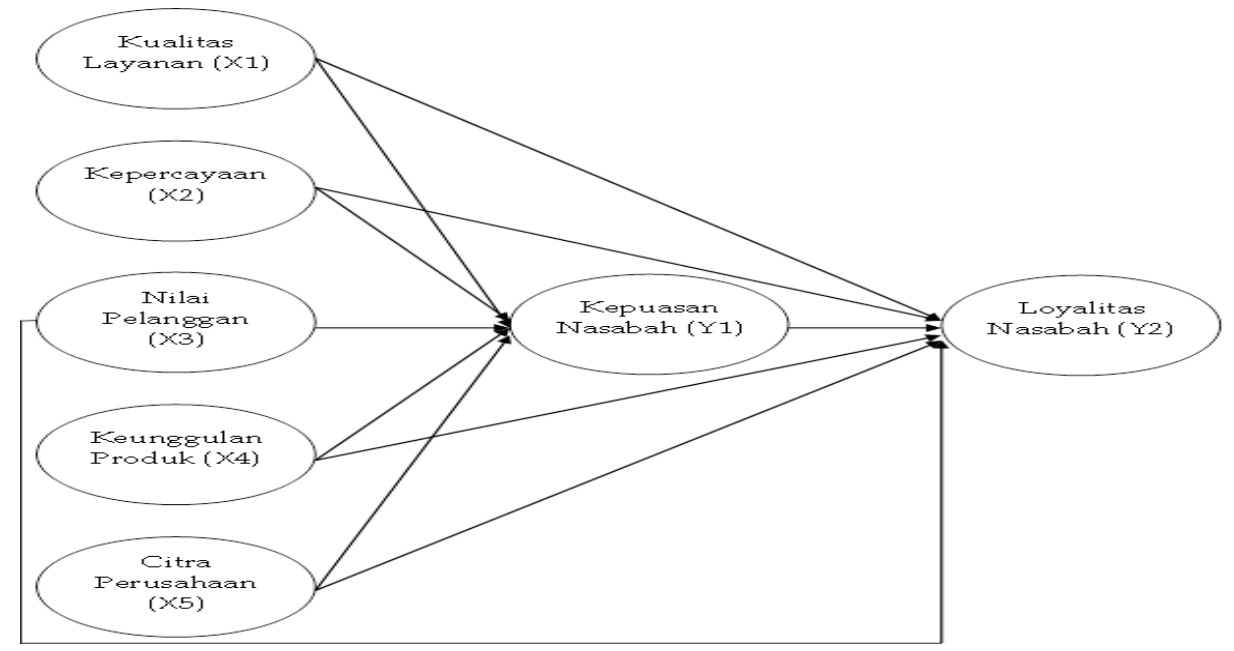

Gambar 1. Kerangka Konseptual Penelitian

Dari uraian di atas, hipotesis yang akan diuji dalam penelitian ini dapat dirumuskan sebagai berikut :

1. Terdapat pengaruh signifikan kualitas layanan terhadap kepuasan nasabah PT BTN Cabang Ambon.

2. Terdapat pengaruh signifikan kepercayaan terhadap kepuasan nasabah PT BTN Cabang Ambon.

3. Terdapat pengaruh signifikan nilai pelanggan terhadap kepuasan nasabah PT BTN Cabang Ambon.

4. Terdapat pengaruh signifikan keunggulan produk terhadap kepuasan nasabah PT BTN Cabang Ambon.

5. Terdapat pengaruh signifikan citra perusahaan terhadap kepuasan nasabah PT BTN Cabang Ambon.

6. Terdapat pengaruh signifikan kualitas layanan terhadap loyalitas nasabah PT BTN Cabang Ambon.

7. Terdapat pengaruh signifikan kepercayaan terhadap loyalitas nasabah PT BTN Cabang Ambon.

8. Terdapat pengaruh signifikan nilai pelanggan terhadap loyalitas nasabah PT BTN Cabang Ambon.

9. Terdapat pengaruh signifikan keunggulan produk terhadap loyalitas nasabah PT BTN Cabang Ambon.

10. Terdapat pengaruh signifikan citra perusahaan terhadap loyalitas nasabah PT BTN Cabang Ambon.

11. Terdapat pengaruh signifikan kepuasan terhadap loyalitas nasabah PT BTN Cabang Ambon. 


\section{METODE PENELITIAN}

Jenis penelitian ini adalah penelitian kuantitatif dengan maksud memeroleh data yang berbentuk angka atau data kualitatif yang diangkakan (Sugiyono, 2006). Penelitian ini dilakukan pada bulan Mei - Juli 2017 pada PT. BTN Cabang Ambon. Data dikumpulkan dengan kuesioner yang disusun menggunakan Skala Likert. Populasi penelitian ini adalah seluruh nasabah PT BTN Cabang Ambon. Sampel yang digunakan diambil dengan teknik accidental sampling, di mana setiap nasabah yang secara kebetulan bertemu pada saat pengambilan data dan bersedia menjadi responden diambil sebagai sampel penelitian. Jumlah sampel ditetapkan sebanyak 125 orang. Analisis data dilakukan dengan analisa jalur, sementara pengujian hipotesis dilakukan dengan Uji t dan Uji F.

\section{PEMBAHASAN}

Karakteristik Responden

Hasil pengolahan data yang dilakukan pada 125 responden diperoleh karakteristik responden menurut jenis kelamin terdapat 79 orang $(63,2 \%)$ lakilaki dan 46 orang $(36,8 \%)$ perempuan. Berdasarkan usia, responden yang berusia 31-50 tahun sebanyak 69 orang $(55,2 \%)$, yang berusia $<30$ tahun sebanyak 22 orang $(17,6 \%)$, dan yang berusia $>50$ tahun sebanyak 34 orang $(27,2 \%)$. Responden yang memiliki pendidikan terakhir di jenjang SMA/sederajat sebanyak 29 orang (23,2\%), Diploma sebanyak 39 orang $(31,2 \%)$, Sarjana sebanyak 47 orang $(37,6 \%)$ serta Pascasarjana sebanyak 10 orang $(8,0 \%)$. Kemudian responden yang memiliki penghasilan $<$ Rp. 5.000.000,- per bulan sebanyak 1 orang $(0,8 \%)$, antara Rp. 5.000.000,- - Rp. 10.000.00,- per bulan sebanyak 57 orang $(45,6 \%)$, serta lebih dari Rp. 10.000.000,- per bulan sebnayak 67 orang $(53,6 \%)$. Selanjutnya, menurut jenis pekerjaan terdapat 24 orang $(19,2)$ responden yang bekerja sebagai PNS, pegawai swasta sebanyak 43 orang $(34,4)$, anggota TNI/Polri sebnayak 31 orang $(24,8 \%)$, professional sebanyak 19 orang $(155,2 \%)$, serta wirausahawan sebanyak 8 orang $(6,4 \%)$.

\section{Hasil Penelitian}

Ringkasan hasil pengujian persamaan I penelitian ini berbentuk persamaan regresi berganda disajikan dalam tabel berikut.

Tabel 1. Ringkasan Hasil Regresi Persamaan I

\begin{tabular}{llrrrrr}
\hline & & \multicolumn{2}{c}{$\begin{array}{l}\text { Unstandardized } \\
\text { Coefficients }\end{array}$} & \multicolumn{2}{c}{$\begin{array}{c}\text { Standardized } \\
\text { Coefficients }\end{array}$} & \\
Model & $\mathrm{B}$ & Std. Error & Beta & $\mathrm{t}$ & \multicolumn{1}{c}{ Sig. } \\
\hline $1 \quad$ (Constant) & 0.881 & .149 & & 5.252 & .000 \\
Kualitas Layanan & .373 & .052 & .395 & 7.179 & .000 \\
Kepercayaan & .077 & .040 & .082 & 1.921 & .006 \\
Nilai Pelanggan & .561 & .134 & .481 & 4.186 & .000 \\
Keunggulan & .244 & .081 & .288 & 3.124 & .002 \\
Produk & & & & & \\
Citra Perusahaan & .108 & .017 & .109 & 6.353 & .010 \\
\hline
\end{tabular}




$\begin{array}{ll}\mathrm{R} & =0,981 \\ \mathrm{R}^{2} & =0,963 \\ \text { Std. Error } & =0,155487 \\ \text { F } & =621,222 \\ \text { Sig } & =0,000\end{array}$

Sumber : Hasil Pengolahan, 2017

Berdasarkan tabel 1 di atas, model persamaan I yang diperoleh dari hasil penelitian ini dapat dituliskan dalam bentuk persamaan regresi berganda adalah :

$Y=0,881+0,373 X_{1}+0,077 X_{2}+0,561 X_{3}+0,244 X_{4}+0,108 X_{5}+0,037$

Dari hasil persamaan regresi tersebut di atas maka dapat dijelaskan :

$\mathrm{b}_{0}=0,881$ merupakan nilai konstanta, artinya tanpa adanya kualitas layanan, kepercayaan, nilai pelanggan, keunggulan produk, dan citra perusahaan, kepuasan nasabah terhadap PT BTN Cabang Ambon sebesar 0,881 atau $88,1 \%$.

$\mathrm{b}_{1}=0,373$ menunjukkan apabila kualitas layanan PT BTN Cabang Ambon Ambon ditingkatkan, sedangkan faktor-faktor lainnya tetap maka akan memengaruhi kepuasan nasabah sebesar 0,373 atau 37,3\%.

$b_{2}=0,077$ menunjukkan apabila kepercayaan nasabah terhadap PT BTN Cabang Ambon ditingkatkan, sedangkan faktor-faktor lainnya tetap, akan memengaruhi kepuasan nasabah sebesar 0,077 atau $7,7 \%$.

$\mathrm{b}_{3}=0,561$ menunjukkan apabila nilai pelanggan (nasabah) ditingkatkan, sedangkan faktor-faktor lainnya tetap, akan memengaruhi kepuasan nasabah sebesar 0,561 atau $56,1 \%$.

$\mathrm{b}_{4}=0,244$ menunjukkan apabila keunggulan produk yang ditawarkan PT BTN Cabang Ambon ditingkatkan, sedangkan faktor-faktor lainnya tetap, akan memengaruhi kepuasan nasabah sebesar 0,244 atau 24,4\%.

$b_{5}=0,108$ menunjukkan apabila citra perusahaan PT BTN Cabang Ambon bagi nasabah ditingkatkan, sedangkan faktor-faktor lainnya tetap maka akan memengaruhi kepuasan nasabah sebesar 0,108 atau 10,8\%.

$\varepsilon=0,037$ menunjukan nilai residu atau nilai pengaruh dari variabel lain yang tidak diikutkan dalam penelitian ini.

Nilai $\mathrm{R}=0,981$ atau 98,1\% menunjukan hubungan kualitas layanan, kepercayaan, nilai pelanggan (nasabah), keunggulan produk dan citra perusahaan dengan kepuasan nasabah, sedangkan nilai koefisien determinasi $\mathrm{R}^{2}=0,963$ menunjukan kualitas layanan, kepercayaan, nilai pelanggan (nasabah), keunggulan produk dan citra perusahaan secara bersama-sama memengaruhi kepuasan nasabah sebesar 96,3\%, sedangkan sisanya 3,7\% dipengaruhi oleh faktor lain yang tidak ikut diteliti. Hal ini didukung dan diperkuat dengan nilai F-hitung sebesar 621,222 dengan signifikansi 0,000. Standar error estimasi sebesar 0,155487 menunjukan penyimpangan antara persamaan regresi dengan nilai dependen riilnya, di mana semakin kecil nilai standar error estimasi semakin baik persamaan regresi tersebut sebagai alat prediksi. Hasil ini berarti kualitas layanan, kepercayaan, nilai pelanggan (nasabah), keunggulan produk dan citra perusahaan memberikan kontribusi 
sebesar 96,3\% terhadap pembentukan kepuasan nasabah PT BTN Cabang Ambon.

Ringkasan hasil pengujian persamaan II penelitian ini berbentuk persamaan regresi berganda disajikan dalam tabel berikut.

Tabel 2. Ringkasan Hasil Regresi Persamaan II

\begin{tabular}{|c|c|c|c|c|c|c|c|}
\hline & & & \multicolumn{2}{|c|}{$\begin{array}{c}\text { Unstandardized } \\
\text { Coefficients }\end{array}$} & \multirow{2}{*}{$\begin{array}{c}\text { Standardized } \\
\text { Coefficients } \\
\text { Beta } \\
\end{array}$} & \multirow[b]{2}{*}{$\mathrm{t}$} & \multirow[b]{2}{*}{ Sig. } \\
\hline \multicolumn{3}{|c|}{ Model } & B & Std. Error & & & \\
\hline \multirow[t]{12}{*}{1} & \multicolumn{2}{|c|}{ (Constant) } & 0.657 & .156 & & 4.211 & .000 \\
\hline & \multicolumn{2}{|c|}{ Kualitas Layanan } & .195 & .052 & .215 & 3.729 & .000 \\
\hline & \multicolumn{2}{|c|}{ Kepercayaan } & .108 & .034 & .109 & 3.177 & .008 \\
\hline & \multicolumn{2}{|c|}{ Nilai Pelanggan } & .204 & .121 & .214 & 1.686 & .010 \\
\hline & \multicolumn{2}{|c|}{$\begin{array}{l}\text { Keunggulan } \\
\text { Produk }\end{array}$} & .308 & .153 & .410 & 2.013 & .047 \\
\hline & \multicolumn{2}{|c|}{ Citra Perusahaan } & .115 & .043 & .196 & 2.674 & .030 \\
\hline & \multicolumn{2}{|c|}{$\begin{array}{l}\text { Kepuasan } \\
\text { Nasabah }\end{array}$} & .979 & .077 & 1.103 & 12.722 & .000 \\
\hline & $\mathrm{R}$ & $=0,984$ & & & & & \\
\hline & $\mathrm{R}^{2}$ & $=0,967$ & & & & & \\
\hline & \multicolumn{7}{|c|}{ Std. Error $=0,12998$} \\
\hline & \multicolumn{7}{|c|}{$F_{\text {hitung }}=581,787$} \\
\hline & Sig & $=0,000$ & & & & & \\
\hline
\end{tabular}

Sumber : Hasil Pengolahan, 2017

Berdasarkan tabel 2 di atas, model persamaan II yang diperoleh dari hasil penelitian ini dapat dituliskan dalam bentuk persamaan regresi berganda adalah :

$$
Y=0,657+0,195 X_{1}+0,108 X_{2}+0,204 X_{3}+0,308 X_{4}+0,115 X_{5}+0,979 Y_{1}+0,037
$$

Dari hasil persamaan regresi tersebut di atas maka dapat dijelaskan :

$\mathrm{b}_{0}=0,657$ merupakan nilai konstanta, artinya tanpa adanya kualitas layanan, kepercayaan, nilai pelanggan, keunggulan produk, citra perusahaan, dan kepuasan nasabah, loyalitas nasabah terhadap PT BTN Cabang Ambon sebesar 0,657 atau $65,7 \%$.

$\mathrm{b}_{1}=$ 0,195 menunjukkan apabila kualitas layanan PT BTN Cabang Ambon Ambon ditingkatkan, sedangkan faktor-faktor lainnya tetap maka akan memengaruhi loyalitas nasabah sebesar 0,195 atau 19,5\%.

$\mathrm{b}_{2}=0,108$ menunjukkan apabila kepercayaan nasabah terhadap PT BTN Cabang Ambon ditingkatkan, sedangkan faktor-faktor lainnya tetap, akan memengaruhi loyalitas nasabah sebesar 0,108 atau 10,8\%.

$\mathrm{b}_{3}=0,204$ menunjukkan apabila nilai pelanggan (nasabah) ditingkatkan, sedangkan faktor-faktor lainnya tetap, akan memengaruhi loyalitas nasabah sebesar 0,108 atau 10,8\%. 
$\mathrm{b}_{4}=0,308$ menunjukkan apabila keunggulan produk yang ditawarkan PT BTN Cabang Ambon ditingkatkan, sedangkan faktor-faktor lainnya tetap, akan memengaruhi loyalitas nasabah sebesar 0,308 atau 30,8\%.

$\mathrm{b}_{5}=0,115$ menunjukkan apabila citra perusahaan PT BTN Cabang Ambon bagi nasabah ditingkatkan, sedangkan faktor-faktor lainnya tetap maka akan memengaruhi loyalitas nasabah sebesar 0,115 atau 11,5\%.

$\varepsilon=0,033$ menunjukan nilai residu atau nilai pengaruh dari variabel lain yang tidak diikutkan dalam penelitian ini.

Nilai $\mathrm{R}=0,984$ atau 98,4\% menunjukan hubungan kualitas layanan, kepercayaan, nilai pelanggan (nasabah), keunggulan produk, citra perusahaan dan kepuasan nasabah dengan loyalitas nasabah, sedangkan nilai koefisien determinasi $\mathrm{R}^{2}=0,967$ menunjukan kualitas layanan, kepercayaan, nilai pelanggan (nasabah), keunggulan produk, citra perusahaan, dan kepuasan nasabah secara bersama-sama memengaruhi loyalitas nasabah sebesar 96,7\%, sedangkan sisanya 3,3\% dipengaruhi oleh faktor lain yang tidak ikut diteliti. Hal ini didukung dan diperkuat dengan nilai F-hitung sebesar 581,787 dengan signifikansi 0,000. Standar error estimasi sebesar 0,12998 menunjukan penyimpangan antara persamaan regresi dengan nilai dependen riilnya, di mana semakin kecil nilai standar error estimasi semakin baik persamaan regresi tersebut sebagai alat prediksi. Hasil ini berarti kualitas layanan, kepercayaan, nilai pelanggan (nasabah), keunggulan produk, citra perusahaan dan kepuasan nasabah memberikan kontribusi sebesar $96,7 \%$ terhadap pembentukan loyalitas nasabah PT BTN Cabang Ambon.

\section{Pengujian Hipotesis}

Tabel 1 di atas menunjukan nilai t-hitung variabel kualitas layanan sebesar 7.179 dengan level signifikansi 0,000 sementara nilai t-tabel adalah 2,62 dengan demikian nilai t-hitung $>$ t-tabel, sehingga hipotesis 1 yang diajukan dalam penelitian ini dapat diterima, di mana kualitas layanan berpengaruh positif dan signifikan terhadap kepuasan nasabah PT BTN Cabang Ambon. Kemudian nilai t-hitung variabel kepercayaan sebesar 1.921 dengan level signifikansi 0,006 dengan demikian nilai t-hitung < t-tabel, sehingga hipotesis 2 yang diajukan tidak dapat diterima, di mana kepercayaan berpengaruh positif tetapi tidak signifikan terhadap kepuasan nasabah PT BTN Cabang Ambon. Nilai t-hitung variabel nilai pelanggan sebesar 4.186 dengan level signifikansi 0,000 dengan demikian nilai t-hitung > t-tabel, sehingga hipotesis 3 yang diajukan dapat diterima, di mana nilai pelanggan berpengaruh positif dan signifikan terhadap kepuasan nasabah PT BTN Cabang Ambon. Nilai t-hitung variabel keunggulan produk sebesar 3.124 dengan level signifikansi 0,002 dengan demikian nilai t-hitung $>$ t-tabel, sehingga hipotesis 4 yang diajukan dapat diterima, di mana keunggulan produk berpengaruh positif dan signifikan terhadap kepuasan nasabah PT BTN Cabang Ambon. Nilai t-hitung variabel citra perusahaan sebesar 6.353 dengan level signifikansi 0,010 dengan demikian nilai t-hitung $>$ t-tabel, sehingga hipotesis 5 yang diajukan dapat diterima, di mana citra perusahaan berpengaruh positif dan signifikan terhadap kepuasan nasabah PT BTN Cabang Ambon. 
Tabel 2 di atas menunjukan nilai t-hitung variabel kualitas layanan sebesar 3.729 dengan level signifikansi 0,000 sementara nilai t-tabel adalah 2,62 dengan demikian nilai t-hitung $>\mathrm{t}$-tabel, sehingga hipotesis 6 yang diajukan dalam penelitian ini dapat diterima, di mana kualitas layanan berpengaruh positif dan signifikan terhadap loyalitas nasabah PT BTN Cabang Ambon. Kemudian nilai t-hitung variabel kepercayaan sebesar 3.177 dengan level signifikansi 0,008 dengan demikian nilai t-hitung < t-tabel, sehingga hipotesis 7 yang diajukan tidak dapat diterima, di mana kepercayaan berpengaruh positif tetapi tidak signifikan terhadap loyalitas nasabah PT BTN Cabang Ambon. Nilai t-hitung variabel nilai pelanggan sebesar 1.686 dengan level signifikansi 0,010 dengan demikian nilai t-hitung $<\mathrm{t}$-tabel, sehingga hipotesis 8 yang diajukan dapat diterima, di mana nilai pelanggan berpengaruh positif tetapi tidak signifikan terhadap loyalitas nasabah PT BTN Cabang Ambon. Nilai thitung variabel keunggulan produk sebesar 2.013 dengan level signifikansi 0,047 dengan demikian nilai t-hitung > t-tabel, sehingga hipotesis 9 yang diajukan dapat diterima, di mana keunggulan produk berpengaruh positif dan signifikan terhadap loyalitas nasabah PT BTN Cabang Ambon. Nilai t-hitung variabel citra perusahaan sebesar 2.674 dengan level signifikansi 0,030 dengan demikian nilai t-hitung $>\mathrm{t}$-tabel, sehingga hipotesis 10 yang diajukan dapat diterima, di mana citra perusahaan berpengaruh positif dan signifikan terhadap loyalitas nasabah PT BTN Cabang Ambon. Selanjutnya nilai t-hitung variabel kepuasan nasabah sebesar 12.722 dengan level signifikansi 0,000 dengan demikian nilai t-hitung $>\mathrm{t}$-tabel, sehingga hipotesis 11 yang diajukan dapat diterima, di mana kepuasan nasabah berpengaruh positif dan signifikan terhadap loyalitas nasabah PT BTN Cabang Ambon.

Hasil pengujian hipotesis menunjukan tidak semua hipotesis yang diajukan dalam penelitian ini dapat diterima. Hipotesis

\section{Pembahasan}

Hasil penelitian ini menunjukan variabel kualitas layanan, kepercayaan, nilai nasabah, keunggulan produk, dan citra perusahaan berpengaruh positif terhadap kepuasan nasabah. Demikian pula variabel kualitas layanan, kepercayaan, nilai nasabah, keunggulan produk, citra perusahaan, dan kepuasan nasabah berpengaruh positif terhadap loyalitas nasabah.

Kualitas layanan merupakan variabel yang memengaruhi baik kepuasan maupun loyalitas nasabah. Layanan yang berkualitas memadukan secara proporsional faktor bukti fisik, keandalan, daya tanggap, jaminan dan empati (Parasuraman, et al., 1988). Karena itu peningkatan layanan agar tetap berkualitas merupakan hal penting yang perlu mendapat perhatian dari penyelenggara atau pemasar jasa. Hal ini dikarenakan karakteristik jasa yang tidak berwujud, tidak memindahkan kepemilikan, serta aktivitas produksi dan konsumsi terjadi pada saat yang bersamaan. Layanan yang diterima nasabah dari pihak PT BTN Cabang Ambon akan menentukan puas atau tidaknya nasabah, begitu pula loyal ataua tidaknya mereka terhadap pemberi jasa.

Kepercayaan merupakan wujud dari komitmen dari satu pihak terhadap pihak lainnya, karena itu penyelenggara atau pemasar jasa senantiasa perlu berupaya optimal untuk menumbuhkan kepercayaan dari nasabah atau 
pelanggan yang dilayani. Tingkat kepercayaan nasabah akan memengaruhi terbentuknya kepuasan atau ketidakpuasan nasabah terhadap pihak PT BTN Cabang Ambon. Demikian pula tingkat kepercayaan nasabah akan menentukan apakah mereka akan loyal atau tidak terhadap pemberi jasa.

Nilai pelanggan merupakan hasil evaluasi atas pengorbanan yang diberikan dengan manfaat yang diperoleh dari suatu aktivitas. Karena itu nilai yang dimiliki nasabah akan memengaruhi tingkat kepuasan atau ketidakpuasan mereka atas interaksi yang terjadi dengan pihak PT BTN Cabang Ambon. Demikian pula nilai yang dimiliki nasabah akan ikut menentukan apakah mereka akan loyal atau tidak terhadap pemberi jasa.

Keunggulan yang dimiliki oleh suatu produk menunjukan superioritasnya atas produk yang sama dari para pesaing. Produk yang unggul tentu memiliki nilai lebih bagi nasabah. Karena itu pihak penyelenggara atau pemasar jasa senantiasa perlu memerhatikan keunggulan dari produk yang ditawarkan. Persepsi nasabah atas keunggulan produk sebagaimana hasil penelitian ini juga merupakan penentu tingkat kepuasan atau ketidakpuasan mereka. Demikian pula dengan loyalitasnya terhadap pemberi jasa atau penyedia produk.

Citra perusahaan merupakan gambaran ideal tentang penyelenggara atau penyedia jasa dalam benak nasabah yang dilayaninya. Karena itu penyelenggara jasa perlu secara terus-menerus berupaya menunjukan citra perusahaan yang positif bagi nasabahnya. Dengan citra perusahaan yang positif bagi nasabah, akan ikut memengaruhi tingkat kepuasan atau ketidakpuasan mereka. Demikian pula dengan pembentukan loyalitasnya.

Hasil penelitian ini sejalan dengan beberapa hasil study empiris yang menunjukan loyalitas nasabah sangat dipengaruhi oleh kepuasan dari nasabahnya (Fornell, 1992), di mana faktor-faktor yang memengaruhi kepuasan nasabah adalah keunggulan produk (Mital et al, 1998), Rasa Percaya (Doney dan Cannon, 1997), nilai nasabah (Slater dan Narver, 1994), Kualitas Layanan (Parasuraman, Zeithaml dan Berry (1985; 1988; 1990 dan 1994), dan citra perusahaan (Fornell, 1992). Hasil penelitian ini mempertegas hasil penelitian terdahulu yang dilakukan oleh Mital et al. (1998), Doney dan Cannon (1997), Slater dan Narver (1994), Butz dan Goodstein (1996), Parasuraman (1998); Aaker dan Keller (1990), Fornell (1992), Saleky, et al. (2014a, 2014b, 2015, 2016), Saleky (2017), Pary (2017), dan Salhuteru (2017) yang menunjukkan hasil bahwa keunggulan produk, rasa percaya, nilai nasabah, kualitas layanan dan citra perusahaan mempunyai pengaruh positif terhadap kepuasan pelanggan (nasabah).

\section{PENUTUP}

\section{Kesimpulan}

Berdasarkan pembahasan diatas diambil kesimpulan sebagai berikut:

1. Kualitas layanan berpengaruh positif terhadap kepuasan dan loyalitas nasabah PT BTN Cabang Ambon.

2. Kepercayaan berpengaruh positif terhadap kepuasan dan loyalitas nasabah PT BTN Cabang Ambon. 
3. Nilai nasabah berpengaruh positif terhadap kepuasan dan loyalitas nasabah PT BTN Cabang Ambon.

4. Keunggulan produk berpengaruh positif terhadap kepuasan dan loyalitas nasabah PT BTN Cabang Ambon.

5. Citra perusahaan berpengaruh positif terhadap kepuasan dan loyalitas nasabah PT BTN Cabang Ambon.

6. Kepuasan nasabah berpengaruh positif terhadap loyalitas nasabah PT BTN Cabang Ambon.

Saran

Berdasarkan hasil pembahasan dan kesimpulan penelitian ini, maka disarankan agar PT BTN cabang Ambon senantiasa berusaha meningkatkan pelayanan yang diberikan bagi nasabah, karena pelayanan yang berkualitas merupakan pangkal dari terbentuknya kepercayaan dan nilai nasabah. Selain itu pihak BTN Cabang Ambon juga senantiasa perlu memertahankan keunggulan produk yang ditawarkan dan citra perusahaannya agar tetap positif dalam benak nasabah yang dilayaninya.

\section{DAFTAR PUSTAKA}

Aaker David A and Kevin L. Keller. 1990. Consumer Evaluations of Brand Extention, Journal of Marketing, 54 (Januari), 27-41.

Anderson, E. and B. Weitz. 1992. The Use of Pledges to Build and Sustain Commitment in Distribution Channel, Journal of Marketing Research, 29(1), 18-34

Awaluddin, Murtiadi, 2013. Pengaruh Independensi dan Kompetensi Auditor Terhadap Kepuasan Kerja dan Kinerja Auditor Inspektorat Kota Makassar. Jurnal Assets, 3.

Awaluddin, Murtiadi. (2016). Pengaruh Budaya Organisasi, Kepuasan dan Lingkungan Kerja terhadap Kinerja Dosen UIN Alauddin Makassar. In Assets (Vol. 6, No. 1, pp. 116-125).

Band, William, A. 1991. CreatingValue for Customers, John Wiley and Sons Inc.

Butz, Howard E and Goodstein, Leonard D. 1996. Marketing Customer Value: Gaining the Strategic Advantage

Doney, Patricia M and Cannon, Joseph P. 1997. An Examination of the nature of trust in buyer-seller relationships, Journal of Marketing, Vol.61, 35-51

Efendi, Ahmad. (2017). Pengaruh Atribut Produk dan Perilaku Pencarian Variasi terhadap Perilaku Mahasiswa Berpindah Merek Ponsel pada Fakultas Ekonomi dan Bisnis Islam UINAM. Jurnal Manajemen Ide dan Inspirasi, 4(2), 63-75.

Efendi, Ahmad. (2018). Analisis Positioning Industri Perbankan Syariah di Indonesia. Al-Mashrafiyah (Jurnal Ekonomi, Keuangan dan Perbankan Syariah), 1(1).

Effendi, Ahmad., 2014. Pengaruh Diversifikasi Program Studi Terhadap Minat Kuliah Mahasiswa Pada Universitas Islam Negeri Alauddin Makassar. AlHikmah Journal for Religious Studies, 15(2), pp.206-219. 
Engel, J.F., Blackwell, R.D. and Miniard, P.W. 1995. Consumer Behavior, $8^{\text {th }}$ Ed, Orlando: The Dryden Press.

Fornell, C. 1992. A National Customer Satisfaction Barometer : The Swedish Experience, Journal Marketing.

Gasperz, V. 1997. Manajemen Kualitas: Penerapan Konsep-Konsep Kualitas dalam Manajemen Bisnis Total, Jakarta: Gramedia Pustaka Utama,.

Gatignon, Hubert and Jean-Marc Xuereb. 1997. Strategy Orientation of the Firm and New Product Performance, Journal of Marketing Research, Vol. XXXIV, 77-90

Kertajaya, Hermawan. 1999. Marketing Plus Siasat Memenagkan Persaingan Global, Jakarta : Gramedia Pustaka Utama

Kotler, Philip. 1997. Marketing Management: Analysis, Planning, Implementation, and Control, 9th Ed., Englewood Cliffs, NJ: Prentice Hall, Inc.

Li, Tiger, and Roger J Calantone. 1998. The Impact of Market Knowledge Competence on New Product Advantage: Conceptualization and Empirical Examination, Journal of Marketing, Vol. 62, Oktober, 13-29

Lovelock, Christoper. 1988. Managing Service: Marketing, Operations and Human Resources, London: Prentice Hall Int Inc.

Mital, Vikas, William T. Ross and Patrick M Baldasare. 1998. The Asymetric Impact of Negative and Positive Attribute Level Performance on Overall Satisfaction and Repurchase Intentions, Journal of Marketing, Vol.62, 33-47

Nurfarhana, S., \& Said, Salmah. (2017). Pendekatan Syariah dalam Pemberian Gaji dan Bonus Pengaruhnya terhadap Motivasi Kerja Pegawai. AlMashrafiyah (Jurnal Ekonomi, Keuangan dan Perbankan Syariah), 1(1).

Oliver, Richard L. 1997. Satisfaction: A. Behavioral Perspective on The Consumer, New York: McGraw-Hill

Parasuraman, A., Berry, L.L., and Zeithaml, A.V. 1985. A Conceptual Model of Service Quality and Its Service Quality and Its Implication for Future Research, in B.M. Enis, K.K. Cox, and M.P. Mokwa (Eds), Marketing Classics: A Selections of Influential Articles, 8th Ed., Engewood, Cliffs, NJ: Prentice Hall International, Inc.

Parasuraman, A., Berry, L.L., and Zeithaml, A.V. 1988. SERVQUAL: A Multiple Item Scale for Measuring Consumer Perceptions of Service Quality, Journal of Retailing, Vol. 64, No. 1, Spring, 12-40.

Parasuraman, A., Berry, L.L., and Zeithaml, A.V. 1990. Delivery Quality Service: Balancing Customer Perceptions and Expectation, New York: The Free Press Adivision of Macmillan, Inc.

Parasuraman. A., Zeithaml, V.A. and Berry, L.L. 1994. Reassessment of Expectations as a Comparison Standar in Measuring Service Quality: Implication for Further Research, Journal of Marketing, January (58): 111124.

Parmitasari, Rika Dwi Ayu, Djabir Hamzah, Syamsu Alam, \& Abdul Rakhman Laba. (2018). Analysis of Ethics and Investor Behavior and Its Impact on Financial Satisfaction of Capital Market Investors. Scienctific Research Journal (SCIRJ), Vol. 4, Issue I, 2018 
Parmitasari, Rika Dwi Ayu., 2011. Struktur Organisasi Dan Kepuasan Kerja Karyawan. Samata: Alauddin University Press

Pary, Gilman. 2017. Faktor yang Memengaruhi Kepuasan Nasabah Bank

Muamalat Cabang Ambon, Jurnal Manajemen Ide dan Inspirasi, Vo. 4, No. 2,

Desember

Said, Salmah. (2015). Sharia Banking Performance in Makassar. Al-Ulum: Jurnal Studi Islam, 15(1), 21-42.

Said, Salmah., \& Amiruddin, A. M. A. (2016). Social Entrepreneurship: Initiative Efforts from Higher Education Classrooms.

Saleky , Saul Ronald Jacob. 2017. Determinan Loyalitas Pelanggan Domestik Garuda Indonesia di Kota Ambon, Jurnal Manajemen Ide dan Inspirasi, Vo. 4, No. 1, Juni

Saleky, Saul Ronald Jacob, Dian Utami Sutiksno, Aldina Shiratina, 2014, The Effect of Service Quality on Customer Satisfaction of The Manise Hotel in Ambon, Indonesia, Proceeding of $2^{\text {nd }}$ GARCOMBS

Saleky, Saul Ronald Jacob, Wendy Souisa, Wylda Olivia Kowey, dan Herlina Syarifuddin. 2016. The Association of Service Quality, Price of Service and Brand Equity on Customer Satisfaction and Retention of Star-Hotel Guests in Ambon, Maluku Province, in Bendesa, I.K. G., Meydianawathi, L.G., Handra, Hefrizal., Hartono, Djoni., Priyarsono, D.S., Resosudarmo, Budi P., and Yusuf, Arif A., 2016. Tourism and Sustainable Development in Indonesia, IRSA Serial Book No. 14

Saleky, Saul Ronald Jacob, Wendy Souisa, Wylda Olivia Kowey, Herlina Syarifuddin. 2015. Contribution of Service Quality, Price of Service and Brand Equity on Customer Satisfaction and Retention of Star Hotel Users in Ambon Town, Proceeding 5th IRSA Institute Conference

Salhuteru, Andrie Ch. 2017. Pengaruh Kualitas Layanan Dan Kepuasan Pasien Terhadap Words of Mouth Pada Rumah Sakit Umum Daerah Dr. M. Haulussy Ambon, Jurnal Manajemen Ide dan Inspirasi, Vo. 4, No. 1, Juni, 8494

Selnes, Fred, 1993. An Examination of the Effect of Product Performance on Brand Reputation, Satisfaction and Loyalty, European Journal of Marketing, 27 (9), 19-35

Shantiuli, T. M., \& Said, S. (2014). Banking with the patron: a case study of patron-client relations in Makassar, Indonesia. Retrieved APril, 30, 2014.

Sinkula, James M, William E. Baker and Thomas Noordewier. 1997. A Framework for Market Based Organizational Leraning : Linking Values, Knowledge, and Behavior, Journal of the Academy of Marketing Science, Vol. 25, No.4, 305-318

Slater, S.F. and Narver, J.C. 1994. Does Competitive Environment Moderate The Market Orientation - Perfomance Relationship, Journal of Marketing, Vol. 58.

Song, Michal and Parry, Mark E. 1997. A Croos National Comparative Study of New Product Development Process : Japan and the US", Journal of Marketing

Sugiyono. 2006. Metode Penelitian Bisnis. Bandung: Alfabeta 
Suhartini, Eka., \& Anisa, N. (2017). Pengaruh Kecerdasan Emosional Dan Kecerdasan Spiritual Terhadap Kinerja Perawat Rumah Sakit Daerah Labuang Baji Makassar. Jurnal Manajemen Ide dan Inspirasi, 4(01).

Suhartini, Eka., 2012. Kualitas pelayanan kaitannya dengan kepuasan konsumen. Alauddin University Press.

Suhartini, Eka., 2013. Motivasi, Kepuasan Kerja dan Kinerja. Samata: Alauddin University Press

Syariati, Alim \& Namla Elfa Syariati. 2012. Islamic Bank as Bank of Ethics. In Proceeding of Annual South East Asian International Seminar.

Syariati, Alim. 2012. The Effect Of Islamic Comercial Banks'health And Their Cost Of Fund Upon Its Financing In Indonesia Over 2005-2009. Proceeding of International Conferrence of AIMI Indonesia

Sylvana, Andi., Si, M. and Murtiadi Awaluddin. (2017). Model Penciptaan Daya Saing Bisnis Melalui Transformasi Kewirausahaan Berbasis Tekhnologi Informasi (Technopreneur). Entrepreneurship at Global Crossroad: Challenges and Solutions, p.71.

Tax, R, Stephen Brown and Chandrasekaran. 1998. Customer Evaluations of Service Complaint Experiences: Implications for Relationship Marketing, Journal of Marketing, Vol. 61

Too Leanne H.Y, Souchon Anne L, and Thirkell Peter C. 2000. Relationship Marketing and Customer Loyalty in A Retail Saetting: A Dyadic Exploration, Aston Bussines School Research Institute, ISBN No.185449 520 8, June, 1-36

Tse, DK., Wilton, PC. 1988. Models of Consumer Satisfaction Formation: An Extension, Journal of Marketing Research, Vol. 25, No. 2, 204-12

Urban Glen L. \& Hauser John R. 1998. Desight and Marketing of New Products, Prentice Hall Inc

Woodruff, Robert B., 1997. Customer Value : The Next Source for Competitive Advantage, Journal of Academy of Marketing Science, Vol 25, No.2, 139-153

Zeithaml, Valerie A, 1987. Defining and Relaying Price, Perceived Quality, and Perceived Value, Marketing Science Institute, Cambridge, MA Report No.87-101 